\title{
Pengaruh Ukuran Perusahaan, Opini Audit, Umur Perusahaan, Profitabilitas dan Solvabilitas Terhadap Audit Delay
}

\author{
Alan Darma Saputra \\ Universitas Prima Indonesia \\ Medan, Indonesia \\ alandarma66@gmail.com
}

\author{
Chalisa Rahmi Irawan \\ Universitas Prima Indonesia \\ Medan, Indonesia \\ Irawan.daughter@gmail.com
}

\author{
Wenny Anggresia Ginting \\ Lecturer at UNPRI \\ Medan, Indonesia \\ gintinganggresiawenny@ gmail.com
}

Corresponding Author : Alan Darma Saputra

Submitted: 4 Juni 2020

Accepted: 22 Juni 2020

Published: 1 Agustus 2020

\section{ABSTRAK}

Tujuan penelitian untuk mengetahui pengaruh dari variabel ukuran perusahaan, opini audit, umur perusahaan, profitabilitas, dan solvabilitas. Data populasi mencakup perusahaan jasa yang terdaftar dalam Bursa Efek Indonesia (BEI) pada tahun 2016-2018. Sampel data yang digunakan merupakan hasil dari teknik purposive sampling dan jumlah sampel yang layak digunakan sebanyak 192 perusahaan. Selama penelitian dilaksanakan, metode yang digunakan yaitu metode analisis regresi logistik dengan penggunaan program SPSS 24. Berdasarkan hasil pengujian oleh peneliti, variabel yang diketahui dapat mempengaruhi audit delay yakni ukuran perusahaan dan umur perusahaan yang bersifat negatif dan secara signifikan. Namun, variabel yang tidak berpengaruh terhadap audit delay yakni opini audit, profitabilitas, dan solvabilitas.

\begin{abstract}
The purpose of this research to determine the influence of the variable company size, audit opinion, company age, profitability, and solvency. Population data includes service companies listed on the Indonesia Stock Exchange (IDX) from 2016 to 2018. The sample data used is the result of the purposive sampling technique and the samples declared worthy to be utilized are 192 companies. During the study conducted, the method was adopted which is a method of logistic regression analysis using SPSS 24.0 program aid. The results of the research show that the variables that are known can affect the audit delay are company size and company's age affect negatively and significantly. Meanwhile, variables that do not affect the audit delay are audit opinions, profitability, and solvency.
\end{abstract}

Keywords: Audit Delay, Audit Opinion, Company's Age, Company Size, Profitability, Solvency. 


\section{PENDAHULUAN}

Laporan kinerja perusahaan dalam suatu perusahaan mencerminkan hasil akhir dalam proses akuntansi yang diharapkan dapat memberikan keterangan yang relevan dan akurat kepada para investor sebagai bagian dari bahan pembahasan terhadap proses pengambilan keputusan atas penanaman modal investor. Keterangan atau informasi yang terkandung dalam perincian hasil kinerja suatu perusahaan harus bersifat relevan dan akurat. Hal ini menunjukkan bahwa suatu laporan hasil kinerja perusahaan yaitu laporan keuangan perlu dilaksanakan pemeriksaan lebih lanjut agar dapat dipertanggungjawabkan kepada pihak yang bersangkutan.

Laporan kinerja perusahaan dalam bentuk laporan keuangan sebaiknya disampaikan sesuai dengan waktu yang telah ditentukan untuk menghindari ketidak akuratan informasi. Penyampaian laporan kinerja perusahaan sesuai dengan waktunya dapat menjadi suatu tolak ukur dalam memperhitungkan kualitas perusahaan dan pengambilan ketentuan yang dilakukan oleh investor. Sedangkan penyampaian hasil kinerja perusahaan yang tidak sesuai dengan waktunya akan menimbulkan efek negatif bagi investor. Hal ini terjadi karena adanya keterlambatan informasi yang disampaikan oleh perusahaan disebabkan karena adanya kondisi yang tidak sehat dalam perusahaan tersebut.

Penyampaian laporan kinerja perusahaan berupa laporan keuangan tahunan beserta hasil audit terhadap laporan kinerja perusahaan dalam bentuk laporan auditor independen yang ditujukan untuk pihak bapepam dan pengumuman yang ditujukan secara umum dalam kurun waktu paling lama 90 hari dihitung dari periode tutup buku berakhir. Penyampaian laporan kinerja perusahaan tersebut telah ditetapkan dalam aturan tertulis pada Surat Keputusan Ketua Badan Pengawas Pasar Modal (Bapepam). Peraturan yang mengikat seperti Peraturan
Bapepam No.VIII.G.7 mengenai penyajian laporan keuangan untuk meningkatkan kualitas keterbukaan laporan keuangan dan Peraturan Bapepam No. VIII.G.11 mengenai tanggung jawab terhadap laporan keuangan oleh pihak direksi. Penyampaian laporan keuangan perusahaan go-public yang telah terdaftar di BEI juga diatur dalam Laporan kinerja perusahaan pada Nomor KEP-346/BL/2011 dengan Nomor Peraturan X.K.2. dan Peraturan Pencatatan BEI No. 1-E, mengenai kewajiban penyampaian laporan keuangan.

Berdasarkan data perusahaan secara menyeluruh, jumlah perusahaan yang telah go-public terlambat menyampaikan laporan hasil kinerja perusahaan yakni laporan keuangan perusahaan masih dinilai besar. Data perusahaan yang disortir untuk melaksanakan penelitian yakni selama 3 tahun yaitu tahun 2016 sampai tahun 2018 pada perusahaan jasa, jumlah perusahaan yang telat menyampaikan laporan keuangan selama proses penelitian cukup banyak setelah peneliti menganalisis tanggal pelaporan laporan auditor dan tanggal tutup buku perusahaan. Berikut daftar tabel yang menunjukkan perusahaan yang telat menyampaikan laporan hasil kinerjanya sesuai dengan hasil analisis peneliti.

Tabel 1.1. Jumlah Emiten yang terlambat menyampaikan laporan Keuangan Auditan

\begin{tabular}{|c|c|}
\hline \multicolumn{1}{|l|}{ Tahun } & Jumlah Emiten \\
\hline 2016 & 25 \\
\hline 2017 & 29 \\
\hline 2018 & 33 \\
\hline
\end{tabular}

Penyampaian hasil kinerja perusahaan kepada Bapepam harus diikuti dengan laporan auditor independen yang berisi laporan kinerja perusahaan yang sudah harus ditelusuri oleh auditor independen. Laporan auditor independen terhadap laporan keuangan merupakan bukti bahwa auditor telah melaksanakan proses 
pemeriksaan dalam penyusunan laporan keuangan tersebut. Jangka waktu pemeriksaan yang dilakukan oleh seorang auditor akan memberikan dampak pada jangka waktu penyampaian laporan kepada Bapepam dan pemangku kepentingan maupun masyarakat dalam penggunaan laporan keuangan tersebut.

Jangka waktu pemeriksaan dalam melakukan penilaian terhadap laporan kinerja perusahaan mengenai kewajarannya tergantung pada transaksi yang dilakukan oleh perusahaan. Semakin banyak transaksi yang harus diperiksa akan berdampak pada tingkat kerumitan dalam pemeriksaan dan waktu penyampaian laporan auditor independen kepada perusahaan. Waktu yang dibutuhkan untuk melakukan pemeriksaan dimulai dari tutup buku pada laporan keuangan hingga pemeriksaan siap dilaksanakan dan telah ditandatangai oleh auditor disebut juga sebagai audit delay.

Adapun variabel independen yang diteliti yakni ukuran perusahaan, opini audit, umur perusahaan, profitabilitas, dan solvabilitas serta variabel dependen yang diteliti yakni audit delay.

\section{LANDASAN TEORI}

\subsubsection{Pengertian Ukuran Perusahaan}

Merupakan tolak ukur yang menilai total aset suatu perusahaan.

Indikator ukuran perusahaan adalah sebagai berikut:

Ukuran Perusahaan $=\operatorname{Ln}($ Total Aktiva $)$

\subsubsection{Pengertian Opini Audit}

Merupakan Laporan yang berisikan opini auditor yang berisikan apakah laporan hasil kinerja telah disusun secara wajar atau tidak wajar.

Indikator opini audit adalah Kode dummy 0 untuk pendapat Qualified Opinion berupa pendapat wajar tanpa pengecualian serta pendapat wajar dengan pengecualian. Kode Dummy 1 untuk pendapat Unqualified Opinion berupa pendapat tidak wajar maupun pernyataan tidak memberikan pendapat.

\subsubsection{Pengertian Umur Perusahaan}

Merupakan Jangka waktu berdirinya suatu perusahaan atau lamanya perusahaan telah beroperasi hingga penelitian dilakukan.

Indikator umur perusahaan adalah Lamanya perusahaan tersebut telah berdiri dihitung dari akta pendirian hingga waktu penelitian.

\subsubsection{Pengertian Profitabilitas}

Merupakan rasio keuangan untuk membandingkan hasil dan pencapaian dari kepemilikan perusahaan. Menurut Kasmir, $(2012 ; 196)$ merupakan rasio untuk menilai kemampuan perusahaan dalam mencari keuntungan.

Indikator profitabilitas menurut Sunyoto, $(2013 ; 116)$ adalah sebagai berikut:

Return Of Assets $=\frac{\text { Laba Bersih Setelah Aktiva }}{\text { Total Aktiva }}$

\subsubsection{Pengertian Solvabilitas}

Merupakan Rasio keuangan yang mengukur besarnya total liabilitas dalam membiayai total aset dalam perusahaan. Menurut Kasmir, $(2012$; 151) merupakan rasio yang digunakan untuk mengukur sejauh mana aktiva perusahaan dibiayai dengan utang.

Indikator solvabilitas menurut Kasmir, (2012; 156) adalah sebagai berikut:

Debt Ratio $=\frac{\text { Total Utang }}{\text { Total Aktiva }} \times 100 \%$

\subsubsection{Pengertian Audit Delay}

Merupakan Keterlambatan pelaporan keuangan perusahaan yang melebihi batas pelaporan dan diukur dari akhir periode 
penutupan buku hingga tanggal terbit laporan auditor.

Indikator Audit Delay adalah Jika tanggal penutupan laporan hasil kinerja perusahaan dipublikasi - tanggal terbit laporan auditor lebih kecil atau sama dengan 90 hari maka digolongkan tidak terjadi Audit Delay diberi kode dummy 0. Jika tanggal penutupan laporan hasil kinerha perusahaan dipublikasi - tanggal terbit laporan auditor lebih besar dari 90 hari maka digolongkan terjadi Audit Delay diberi kode dummy 1.

Kerangka Konseptual dapat digambarkan sebagai berikut:

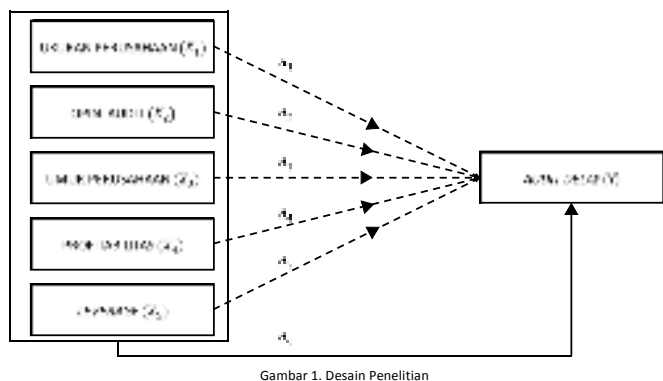

\subsection{Pengembangan Hipotesis}

\subsubsection{Keterkaitan Ukuran Perusahaan Terhadap Audit Delay}

Ukuran perusahaan menjelaskan mengenai seberapa besar atau kecilnya suatu perusahaan yang diukur dari nilai aset yang merupakan kepemilikan perusahaan tersebut. Menurut penelitian Santoso (2012), Haryani (2015), dan Amani \& Waluyo (2016), bahwa besar atau kecilnya ukuran perusahaan berdampak terhadap audit delay. Sedangkan menurut Aditya \& Anisykurlillah (2014) dan Indra \& Arisudhana (2012), bahwa besar atau kecilnya ukuran perusahaan tidak berdampak terhadap audit delay.

Maka peneliti mengajukan hipotesis sebagai berikut:
$\mathbf{H}_{1}$ : Ukuran perusahaan berpengaruh secara positif dan signifikan terhadap audit delay.

\subsubsection{Keterkaitan Opini Audit Terhadap Audit Delay}

Opini audit merupakan kesimpulan yang dikemukakan oleh pihak auditor independen terhadap kewajaran laporan kinerja perusahaan yang disusun oleh perusahaan apakah telah sesuai dengan SAK atau tidak. Menurut penelitian Purnamasari (2011) dan Aditya \& Anisykurlillah (2014), bahwa audit delay dipengaruhi oleh opini audit. Hal ini disebabkan oleh penerimaan opini audit qualified opinion pada perusahaan klien akan meingkatkan persentase terjadinya audit delay meningkat. Namun, penerimaan opini audit unqualified opinion pada perusahaan klien cenderung menurunkan persentase terjadinya audit delay. Jika dilihat pada penelitian Hersugondo \& Kartika (2013) dan Rustiarini \& Sugiarti (2013), hasil penelitian menunjukkan tidak adanya pengaruh yang diberikan oleh opini audit pada audit delay atau dapat dikatakan bahwa audit delay tidak dipengaruhi oleh opini audit.

Maka peneliti mengajukan hipotesis sebagai berikut:

$\mathbf{H}_{\mathbf{2}}$ : Opini audit berpengaruh secara positif dan signifikan terhadap audit delay.

\subsubsection{Keterkaitan Umur Perusahaan Terhadap Audit Delay}

Umur perusahaan merupakan seberapa lama perusahaan telah berdiri hingga waktu penelitian dilakukan. Menurut penelitian Septriana (2010), Lianto \& Kusuma (2010), dan (Indra \& Arisudhana, 2012), bahwa besar kecilnya umur perusahaan berdampak terhadap audit delay. Sedangkan menurut Witjaksono \& Silvia (2014) dan Septriana (2010), bahwa besar kecilnya umur perusahaan tidak memiliki dampak maupun pengaruh pada audit delay. 
Maka peneliti mengajukan hipotesis sebagai berikut:

$\mathbf{H}_{3}$ : Umur perusahaan berpengaruh secara positif dan signifikan terhadap audit delay.

\subsubsection{Keterkaitan Terhadap Audit Delay}

Profitabilitas

Profitabilitas secara umum dinilai sebagai kemampuan suatu perusahaan dalam memperoleh profit dalam suatu waktu atau suatu periode. Semakin tinggi surplusnya profitabilitas suatu perusahaan, maka kesanggupan perusahaan dalam mendatangkan laba bagi perusahaan akan dinilai bagus atau tinggi. Tingkat profitabilitas dapat diukur dengan menggunakan Return On Assets (ROA). Menurut penelitian Lianto \& Kusuma (2010), Amani \& Waluyo (2016), dan (Suparsada \& Putri, 2017), bahwa tingkat profitabilitas dan hasil kinerja yang baik atau buruk dalam suatu perusahaan dapat memberikan pengaruh dalam audit delay. Sedangkan menurut Hersugondo \& Kartika (2013) dan Haryani (2015), bahwa audit delay tidak dipengaruhi oleh tingkat profitabilitas.

Maka peneliti mengajukan hipotesis sebagai berikut:

$\mathbf{H}_{\mathbf{4}}$ : Profitabilitas berpengaruh secara positif dan signifikan terhadap audit delay

\subsubsection{Keterkaitan Terhadap Audit Delay}

Solvabilitas

Berdasarkan penelitian Susilawati et al. (2012), Witjaksono \& Silvia (2014), dan Apriyani (2015) menunjukkan bahwa laporan hasil auditing bergantung pada lamanya proses pemeriksaan yang dilakukan auditor terhadap tingkat besar kecilnya hutang. Hal ini dikarenakan besar kecilnya hutang harus dikonfirmasi oleh pihak auditor melalui surat konfirmasi dan auditor pelu meneleusuri lebih lanjut jika terdapat perbedaan antara pencatatan dengan hasil konfirmasi yang diterima. Hal ini yang memperlambat proses pelaporan audit oleh auditor dan meningkatkan terjadinya audit delay. Sedangkan hasil pengujian Santoso (2012) menunjukkan bahwa besar atau kecilnya solvabilitas tidak memiliki pengaruh terhadap audit delay.

Maka peneliti mengajukan hipotesis sebagai berikut:

$\mathbf{H}_{5}$ : Solvabilitas berpengaruh secara positif dan signifikan terhadap audit delay

\section{METODE PENELITIAN}

Penelitian dilaksanakan dengan menggunakan data sekunder sebanyak 305 populasi perusahaan jasa yang tercatat di Bursa Efek Indonesia pada tahun 2016 hingga 2018 melalui situs www.idx.co.id. Sampel yang dimanfaatkan adalah sebanyak 192 perusahaan dimana data tersebut telah memenuhi kriteria/syarat yang dibuat oleh peneliti. Sampel yang dipakai oleh peneliti dipilah dengan memakai metode purposive sampling dengan kriteria/syarat tertentu yang telah dibuat dan dinyatakan oleh peneliti. Berikut beberapa kriteria yang dibuat oleh peneliti dalam pengambilan sampel pada perusahaan jasa yang terdaftar di Bursa Efek Indonesia:

1. Sampel merupakan perusahaan yang harus tercatat dalam Bursa Efek Indonesia.

2. Sampel merupakan perusahaan yang harus mempublikasi laporan hasil kinerja perusahaan atau laporan kinerja tahunan dari tahun 2016 sampai 2018 secara berurutan.

3. Sampel merupakan perusahaan yang hanya mengalami profit dari tahun 2016 sampai 2018.

Pengujian hipotesis dilaksanakan dengan menggunakan analisis regresi logistik, berikut model regresi logistik tersebut

$$
\begin{aligned}
& \ln \left[\frac{p}{1-p}\right]=\alpha+\beta_{1} U k+\beta_{2} O A+\beta_{3} U m \\
& +\beta_{4} \text { Solv }+\beta_{5} \text { Prof }+\varepsilon
\end{aligned}
$$


Keterangan:

$$
\begin{array}{lll}
\ln \left[\frac{p}{1-p}\right] & =\text { Audit Delay } \\
\alpha & =\text { Konstanta } \\
\beta_{1}-\beta_{5} & =\text { Koefisien Parameter Struktur } \\
\mathrm{Uk} & =\text { Ukuran Perusahaan } \\
\text { OA } & \quad=\text { Opini Audit } \\
\text { Um } & \quad=\text { Umur Perusahaan } \\
\text { Prof } & =\text { ROA } \\
\text { Solv } & =\text { DR } \\
\varepsilon & =\text { Kesalahan Residual }
\end{array}
$$

\section{HASIL DAN PEMBAHASAN}

\subsection{Penilaian Kelayakan Model Regresi}

Dalam menentukan model regresi yang tepat digunakan dalam suatu penelitian, kecocokan atau kelayakan dari penggunaan model regresi secara keseluruhan haruslah diperhatikan. Jumlah sampel yang memenuhi kriteria dalam penelitian ini sebesar 192 perusahaan dengan periode penelitian 2016-2018. Penilaian dilaksanakan dengan melakukan pengujian Hosmer and Lemeshow's Test dengan hasil pengujian pada tabel sebagai berikut:

Tabel 4.1

Hasil Pengujian Hosmer and Lemeshow's Goodness of Fit

\begin{tabular}{|c|c|c|c|}
\hline Hosmer and Lemeshow Test \\
\hline Step & Chi-square & df & Sig. \\
\hline 1 & 8.348 & 8 & 0.4 \\
\hline
\end{tabular}

Sumber: Hasil Pengolahan Data Sekunder (SPSS)

Pada tabel 4.1 di atas, tampak bahwa hasil pengujian menyatakan nilai pada kolom chi-square sebesar 8,348 dimana nilai signifikansi pada hasil pengujian sebesar 0,4 dimana $0,4<0,5$, sehingga penggunaan model regresi logistik layak digunakan dalam melakukan analisa pada tahap selanjutnya. Hal ini disebabkan karena ketiadaan perbedaan yang nyata diantara klarifikasi yang diamati dengan yang diprediksi. Dengan demikian, model ini mampu meramalkan nilai observasinya.

\subsection{Menilai Model Fit}

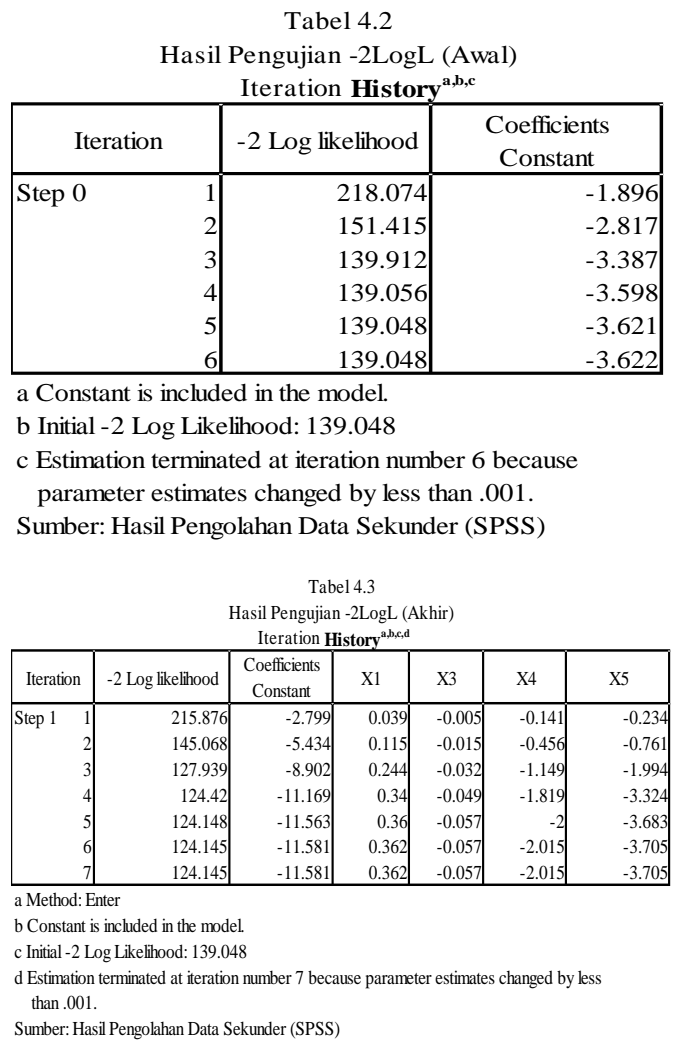

Berdasarkan tabel 4.2 dan tabel 4.3 di atas, tampak bahwa hasil pengujian -2LogL awal adalah sebesar 139,048 dan hasil pengujian -2LogL akhir mengalami penurunan menjadi 124,145. Penurunan yang terjadi adalah sebesar 14,903, nilai tersebut menunjukkan bahwa penambahan variabel independen seperti ukuran perusahaan, opini audit, umur perusahaan, profitabilitas, dan solvabilitas ke dalam model pengujian akan memperbaiki hasil dari pengujian regresi logistik pada model fit.

\subsection{Matrik Klasifikasi}

Matrik klasifikasi menjelaskan seberapa kuat prediksi dari mode regresi dalam memprediksi persentase penerimaan opini audit dalam perusahaan. Nilai matrik ditunjukkan pada tabel sebagai berikut: 


\begin{tabular}{|c|c|c|c|c|c|c|}
\hline & Stati & $\begin{array}{r}\text { Tal } \\
\mathrm{k} \text { Desk }\end{array}$ & $\begin{array}{l}14.4 \\
\text { ptif Opi }\end{array}$ & Audit & & \\
\hline & & Opin & Audit & & & \\
\hline & Qualifiec & pinion & Unq & lified & Total & $\%$ \\
\hline & Jumlah & $\%$ & Jumlah & $\%$ & & \\
\hline Audit Delay & 0 & $0 \%$ & 15 & $3 \%$ & 15 & $3 \%$ \\
\hline Non Audit Delay & 0 & $0 \%$ & 561 & $97 \%$ & 561 & $97 \%$ \\
\hline Total & 0 & & 576 & & 576 & $100 \%$ \\
\hline
\end{tabular}

Berdasarkan tabel 4.4 di atas, dapat dilihat bahwa persentase kuantitas perusahaan dengan opini audit qualified opinion dan terjadinya audit delay sebesar $0 \%$ sedangkan persentase kuantitas perusahaan dengan jenis opini audit unqualified opinion dan terjadinya audit delay yaitu sebesar 3\% yang merupakan 15 data observasi dari 576 data observasi. Persentase kuantitas perusahaan dengan opini audit dan tidak terjadi audit delay sebesar 0\%. Sedangkan persentase kuantitas

\subsection{Analisis Regresi Logistik}

Hasil analisis regresi logistik tampak pada tabel varibles in the equation pada kolom sig. pada tingkat alpha 5\% atau 0,05. Jika nilai sig. < 0,05 maka hipotesis alternatif (Ha) diterima dan Ho ditolak. Hasil analisis tampak pada tabel 4.5 di bawah ini:

\begin{tabular}{|c|c|c|c|c|c|c|c|}
\hline \multicolumn{8}{|c|}{$\begin{array}{l}\text { Tabel } 4.5 \\
\text { Hasil Pengujian Regresi Logistik } \\
\text { Variables in the Equation }\end{array}$} \\
\hline & & B & S.E. & Wald & df & Sig. & $\operatorname{Exp(B)}$ \\
\hline \multirow[t]{5}{*}{ Step 1a } & $\mathrm{X} 1$ & 0.362 & 0.129 & 7.825 & & 0.005 & 1.436 \\
\hline & X3 & -0.057 & 0.023 & 6.314 & & 0.012 & 0.944 \\
\hline & $\mathrm{X} 4$ & -2.015 & 1.209 & 2.776 & & 0.096 & 0.133 \\
\hline & $\mathrm{X} 5$ & -3.705 & 5.063 & 0.536 & & 0.464 & 0.025 \\
\hline & Constant & -11.581 & 3.786 & 9.358 & & 0.002 & \\
\hline
\end{tabular}

$\mathrm{X} 1$ atau ukuran perusahaan memiliki nilai sig. 0,005 $<0,05$ yang menjelaskan bahwa H1 diterima dimana ukuran perusahaan berpengaruh positif terhadap audit delay. $\mathrm{X} 2$ atau opini audit tidak memiliki nilai sig. karena nilai kode dummy pada opini audit cenderung 0 sehingga tidak terjadi pengujian pada opini audit. Sehingga H2 yang menyatakan opini audit berpengaruh secara positif, ditolak. X3 atau umur perusahaan memiliki nilai sig. $0,012<0,05$ yang menjelaskan bahwa $\mathrm{H} 3$ diterima dimana umur perusahaan memiliki pengaruh secara negatif terhadap audit delay. X4 atau Profitabilitas memiliki nilai sig. 0,096 > 0,05 yang menjelaskan bahwa $\mathrm{H} 4$ ditolak dimana profitabilitas tidak memiliki pengaruh terhadap audit delay. X5 atau solvabilitas memiliki nilai sig. 0,464 > 0,05 yang menjelaskan bahwa H5 ditolak dimana solvabilitas tidak memiliki pengaruh terhadap audit delay.

\subsection{Pengujian Hipotesis}

\subsubsection{Pengaruh Ukuran Perusahaan Terhadap Audit Delay}

Hasil pengujian hipotesis mengungkapkan bahwa ukuran perusahaan berpengaruh secara positif. Hasil pengujian memberitahukan bahwa perusahaan dengan ukuran besar akan meningkatkan atau memperbesar kemungkinan tingkat terjadinya audit delay. Sebaliknya, perusahaan dengan ukuran yang masih kecil cenderung akan memperkecil atau memperendah kemungkian terjadinya audit delay. Hal tersebut dikarenakan besarnya ukuran suatu perusahaan berarti jumlah aset yang dimiliki juga cenderung banyak. Sehingga waktu yang diperlukan bagi auditor dalam melaksanakan auditing juga akan lebih lama. Sebaliknya, ukuran perusahaan yang kecil menunjukkan jumlah aset yang lebih kecil dengan jenis aset yang lebih sedikit sehingga membutuhkan waktu yang lebih sedikit untuk kegiatan auditing dilaksanakan. Hasil penelitian ini dapat dilihat pada penelitian Santoso (2012), Haryani (2015), dan Amani \& Waluyo (2016) namun berlawanan dengan hasil penelitian yang dilaksanakan oleh Aditya \& Anisykurlillah (2014) dan Indra \& Arisudhana (2012) yang menerangkan kecenderungan terjadinya audit delay semakin tinggi disebabkan oleh ukuran yang kecil suatu perusahaan, namun terjadinya audit delay semakin rendah atau kecil jika ukuran perusahaanlebih besar. 


\subsubsection{Pengaruh Opini Audit Terhadap Audit Delay}

Hasil pengujian mengungkapkan bahwa opini audit tidak berpengaruh terhadap audit delay. Hal ini dikarenakan varian dari opini audit tidak memiliki perbedaan atau sama. Hal ini serasi dengan hasil penelitian Purnamasari (2011) dan Aditya \& Anisykurlillah (2014) yang mengatakan bahwa audit delay tidak diterangkan oleh opini audit secara signifikan dan hasil tersebut berlawanan dengan hasil penelitian oleh Hersugondo \& Kartika (2013) dan Rustiarini \& Sugiarti (2013) yang mengatakan audit delay dipengaruhi oleh opini audit secara signifikan.

\subsubsection{Pengaruh Umur Perusahaan Terhadap Audit Delay}

Hasil pengujian mengungkapkan hipotesis mengenai audit delay dipengaruhi dengan signifikan oleh umur perusahaan, diterima. Hal tersebut disebabkan oleh umur perusahaan yang besar menunjukkan bahwa perusahaan telah berjalan lama, telah berpengalaman dan mengetahui segala kebutuhan yang dibutuhkan oleh para auditor independen dalam melaksanakan audit pada laporan hasil kinerja perusahaan yang disusun sebagai laporan keuangan sehingga dapat disediakan bagi auditor dalam menjalankan tugasnya. Hasil penelitian ini dapat dilihat dari hasil penelitian oleh Septriana (2010), Lianto \& Kusuma (2010), dan (Indra \& Arisudhana, 2012) namun tidak selaras dengan hasil penelitian Witjaksono \& Silvia (2014) dan Septriana (2010) yang mengatakan bahwa audit delay tidak dipengaruhi oleh umur perusahaan.

\subsubsection{Pengaruh Profitabilitas Terhadap Audit Delay}

Hasil pengujian menunjukkan bahwa hipotesis yang menyatakan audit delay dipengaruhi oleh tingkat profitabilitas secara signifikan, ditolak. Hal tersebut dikarenakan kegiatan auditing yang dilakukan di suatu perusahaan pada tingkat keuntungan yang sedikit maupun besar tidak akan terdapat perbedaan yang signifikan dari segi proses auditing dan prosedur audit yang dilakukan terhadap laporan hasil kinerja perusahaan tersebut. Hasil penelitian ini dapat dilihat dari hasil penelitian Lianto \& Kusuma (2010), Amani \& Waluyo (2016), dan (Suparsada \& Putri, 2017) yang memberitahukan bahwa audit delay tidak dipengaruhi secara signifikan oleh tingkat profitabilitas. Namun berbanding terbalik dengan hasil penelitian Hersugondo \& Kartika (2013) dan Haryani (2015) yang memberitahukan bahwa suatu perusahaan pada tingkat keuntungan yang besar atau tinggi akan memacu auditor dalam melaksanakan proses auditing sehingga kemungkinan terjadinya audit delay menjadi kecil

\subsubsection{Pengaruh Solvabilitas Terhadap Audit Delay}

Hasil dari pengujian memperlihatkan bahwa hipotesis yang menyatakan bahwa terjadinya audit delay yang dipengaruhi secara signifikan dari tingkatan solvabilitas, ditolak. Hal tersebut disebabkan kegiatan auditing atau pemeriksaan yang dilakukan oleh auditor dalam menguji saldo akun hutang yang tertera pada laporan keuangan tidak akan berbeda antara hutang yang tinggi maupun hutang yang rendah karena pengujian saldo akun hutang perusahaan diperlukan ketelitian dan kehati-hatian para auditor. Hasil penelitian ini dapat dilihat dari penelitian Susilawati et al. (2012), Witjaksono \& Silvia (2014), dan Apriyani (2015) yang menyatakan bahwa audit delay tidak terpengaruh secara signifikan oleh tingkat solvabilitas. Namun hal ini berlawanan dengan hasil penelitian Santoso (2012) yang menyatakan bahwa audit delay dipengaruhi secara signifikan oleh tingkat solvabiltias.

\section{KESIMPULAN DAN SARAN \\ 5.1. Kesimpulan}

Berdasarkan hasil analisis regresi logistik, dapat diungkapkan bahwa ukuran 
perusahaan dan umur perusahaan berpengaruh terhadap audit delay. Sedangkan opini audit, profitabilitas, dan solvabilitas tidak memiliki pengaruh terhadap audit delay. Variabel independen yang memberikan pengaruh paling signifikan yakni ukuran perusahaan.

\subsection{Keterbatasan}

Selama melaksanakan penelitian, peneliti menemukan bahwa:

1. Penelitian yang dilakukan hanya berdasarkan data observasi terhadap perusahaan di BEI selama 3 tahun, yaitu periode 2016 sampai 2018.

2. Penelitian ini dilakukan hanya dengan memanfaatkan lima faktor sebagai variabel

bebas/independen yakni ukuran perusahaan, opini audit, umur perusahaan, profitabilitas, dan solvabilitas, yang dinilai kurang efektif dalam menganalisis pengaruh terhadap variabel independennya yaitu audit delay. Hal ini dikarenakan masih terdapat faktor-faktor yang belum diteliti sebelumnya.

3. Penelitian yang dilaksanakan terbatas pada lingkup perusahaan jasa yang tercatat di BEI.

\subsection{Saran}

Dari hasil pembahasan yang sudah dijelaskan di muka, peneliti memberikan sedikit masukan berupa saran yang dapat dipertimbangkan sebagai berikut:

1. Peneliti selanjutnya diusulkan untuk mengambil data observasi yang lebih panjang atau jangka waktu observasi perusahaan tidak terlalu sedikit.

2. Peneliti selanjutnya disarankan untuk memperluas lingkup penelitian jika menggunakan data dari BEI agar perusahaan yang diteliti diharapkan dapat memberikan hasil yang lebih akurat pada jangkauan luas.
3. Peneliti selanjutnya hendaklah meningkatkan banyaknya sampel perusahaan yang digunakan agar hasil penelitian dapat mencerminkan pengaruh yang terjadi secara menyeluruh.

4. Menambah faktor-faktor lainnya yang dianggap dapat meningkatkan persentase pengaruh variabel pada audit delay.

\section{DAFTAR PUSTAKA}

Aditya, A. N., \& Anisykurlillah, I. (2014). Faktor-Faktor yang Berpengaruh Terhadap Audit Delay. Accounting Analysis Journal, 3(3), 334-342.

Amani, F. A., \& Waluyo, I. (2016). Pengaruh Ukuran Perusahaan, Profitabilitas, Opini Audit, dan Umur Perusahaan Terhadap Audit Delay (Studi Empiris pada Perusahaan Property dan Real Estate yang Terdaftar di Bursa Efek Indonesia pada Tahun 20122014). Nominal, Barometer Riset Akuntansi Dan Manajemen, 5(1), 135-150.

https://doi.org/10.21831/nominal.v5i 1.11482

Apriyani, N. N. (2015). Pengaruh Solvabilitas, Opini Auditor, Ukuran KAP, dan Komite Audit Terhadap Audit Delay. Jurnal Akuntansi Dan Sistem Teknologi Informasi, 11(Juni), 169-177.

Ghozali. 2016. Aplikasi Analisis Multivariete dengan Program IBM SPSS 23. Cet. VIII. Semarang: Universitas Diponegoro.

Haryani. (2015). Pengaruh Ukuran Perusahaan, Tingkat Leverage, dan Profitabilitas Terhadap Audit Delay Dengan Kualitas Sebagai Variabel Moderating. Jurnal Akuntansi, 1, 111 .

Hersugondo, \& Kartika, A. (2013). 
Prediksi Probabilitas Audit Delay Dan Faktor Determinannya. Jurnal Ekonomi Manajemen Akuntansi, 20(35), 1-21.

Indra, N. S., \& Arisudhana, D. (2012).

Faktor-Faktor Yang

Mempengaruhi Audit Delay Pada Perusahaan Go Public di Indonesia (Studi Empiris pada Perusahaan Property dan Real Estate di Bursa Efek Indonesia periode 2007-2010). Jurnal Akuntansi Dan Keuangan, I(2), 165-184.

Kasmir. 2012. Analisis Laporan Keuangan. Edisi 1-5, Cetakan ke-5. Jakarta: Rajawali Pers.

Lianto, N., \& Kusuma, B. H. (2010). Faktor-Faktor Yang Berpengaruh Terhadap Audit Delay. Jurnal Bisnis Dan Akuntansi, 12(2), 97-106. https://doi.org/10.15294/aaj.v3i3.420 4

Purnamasari, C. P. (2011). Analisis Faktor-Faktor yang Mempengaruhi Audit Delay pada Perusahaan LQ45 yang Terdaftar di Bursa Efek Indonesia.

Rustiarini, N. W., \& Sugiarti, N. W. M. (2013). Pengaruh Karakteristik Auditor, Opini Audit, Audit Tenure, Pergantian Auditor pada Audit Delay. Jurnal Ilmiah Akuntansi dan Humanika, 2(2), 657-675.

Santoso, F. K. (2012). Analisis FaktorFaktor yang Mempengaruh Audit Delay pada Perusahaan di Sektor Keuangan. Berkala Ilmiah Mahasiswa Akuntansi, 1(2), 89-95.

Septriana, I. (2010). Analisis FaktorFaktor yang Berpengaruh Terhadap Ketepatan Waktu Pelaporan Keuangan Perusahaan BUMN di Indonesia. Jurnal Maksi, 10(1), 97-117.

Sunyoto, Danang. 2013. Analisis Laporan
Keuangan untuk Bisnis. Ed. 1. Yogyakarta: CAPS (Centre of Academic Publishing Service)

Suparsada, N. P. Y. D., \& Putri, I. A. D. (2017). Pengaruh Profitabilitas, Reputasi Auditor, Ukuran Perusahaan, dan Kepemilikan Institusional Terhadap Audit Delay. E-Jurnal Akuntansi, 18, 60-87.

Susilawati, C. D. K., Agustina, L., \& Prameswari, T. (2012). Analisis Faktor-Faktor yang Mempengaruhi Terjadinya Audit Delay Pada Perusahaan Consumer Good Industry di Bursa Efek Indonesia (Periode Tahun 20082010). Akurat: Jurnal Ilmiah Akuntansi, 4(10), 19-30.

Witjaksono, A., \& Silvia, M. (2014). Analisa Faktor-Faktor yang Berpengaruh Terhadap Audit Delay Pada Perusahaan Consumer Goods yang Terdaftar di Bursa Efek Indonesia Periode 2010-2013. Jurnal Keuangan Dan Bisnis, 4(2), 53-64. 